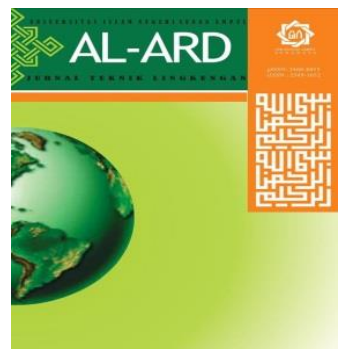

AL-ARD: JURNAL TEKNIK LINGKUNGAN

Vol.4 No.2 - Maret 2019 (11-17)

AL-ARD

JURNAL

TEKNIK LINGKUNGAN

www.al-ard.uinsby.ac.id

\title{
Karakterisasi dan Pemilihan Alat Pengendali Limbah Sandblasting di Bengkel Blasting Industri Konstruksi Kapal
}

\author{
Ahmad Erlan Afiuddin 1, Ragil Zika Hibriza ${ }^{2}$, Dwi Ratri Mitha Isnadina ${ }^{3}$ \\ 1) 2) Politeknik Perkapalan Negeri Surabaya, Surabaya, Indonesia \\ erlan.ahmad@gmail.com ${ }^{1)}$ zikaragil@gmail.com ${ }^{2)}$ \\ ${ }^{3}$ Universitas Airlangga, Surabaya, Indonesia \\ dwi.ratri.m.i@fst.unair.ac.id
}

\begin{abstract}
Sandblasting waste from the blasting process of ship construction has a high potential to pollute the air and a negative impact to the environment or human health. The sandblasting waste from the blasting process of the ship construction industry has not been well managed, evidenced by the concentration of sandblasting waste that exceeds the quality standard that is equal to $6654,54 \mathrm{mg} / \mathrm{m}^{3}$. Therefore, it is necessary to characterize sandblasting waste and to select and apply an appropriate sandblasting waste control device. Identification of characteristics begins with taking particulate samples in locations with high volume air sampler (HVAS) equipment, taking as many as 8 sample points. Identification of sandblasting waste characteristics including concentration, diameter and heavy. Each analysis method used includes gravimetry, scanning electron microscopy (SEM) and atomic absorbtion spectrophotometry (AAS). The average value of sandblasting waste is $6654.54 \mathrm{mg} / \mathrm{m} 3$, the size of sandblasting waste is 1.75 to $63.03 \mu \mathrm{m}$. The measured heavy metal content is Fe and $\mathrm{Al}$ with an average content of 1.64 and $2.29 \mathrm{mg} / \mathrm{m}^{3}$. Control technology that can use for sandblasting waste are gravity settling chamber or cyclone for preremoval and bag filter or scrubber or electrostatic precipitator as an advance removal.

Keywords: Ships construction, sandblasting and particulate control technology
\end{abstract}

\begin{abstract}
Abstrak
Limbah sandblasting dari proses blasting kontruksi kapal memiliki potensi tinggi mencemari udara dan memiliki dampak bahaya bagi lingkungan ataupun kesehatan manusia. Limbah sandblasting yang dihasilkan belum terkelola dengan baik, dibuktikan dengan konsentrasi limbah sandblasting yang melebihi baku mutu yaitu sebesar $6654,54 \mathrm{mg} / \mathrm{m}^{3}$. Berdasarkan kondisi tersebut diperlukan karakterisasi limbah sandblasting dan melakukan pemilihan serta mengaplikasikan suatu alat pengendali limbah sandblasting yang tepat. Identifikasi karakteristik limbah sandblasting diperlukan sebagai dasar dalam menentukan jenis alat pengendali yang tepat. Identifikasi karakteristik dimulai dengan pengambilan sampel partikulat di lokasi dengan peralatan high volume air sampler (HVAS), pengambilan sampel sebanyak 8 titik. Identifikasi karakteristik limbah sandblasting meliputi konsentrasi, diameter dan kandungan logam berat. Masing-masing metode analisa yang digunakan antara lain gravimetri, scanning elektron microscopy (SEM) dan atomic absorbtion spectrophotometry (AAS). Nilai rata-rata konsentrasi limbah sandblasting sebesar $6654,54 \mathrm{mg} / \mathrm{m}^{3}$, ukuran limbah sandblasting sebesar 1,75 sampai 63,03 $\mu \mathrm{m}$. Kandungan logam berat yang diukur adalah Fe dan Al dengan kandungan rata-rata sebesar 1,64 dan 2,29 mg/m³. Teknologi pengendalian bisa menggunakan gravity settling chamber atau cyclone untuk penyisihan pendahuluan dan menggunakan bag filter atau scrubber atau electrostatic precipitator sebagai penyisihan lanjutan.

Kata Kunci: Konstruksi kapal, sandblasting, dan teknologi pengendalian partikulat
\end{abstract}

\section{PENDAHULUAN}

Seiring dengan berkembangnya dunia maritim di Indonesia maka industri di bidang konstruksi kapal juga akan berkembang.
Proses pembuatan kapal memiliki banyak tahapan proses dan membutuhkan waktu berbulan-bulan atau bertahun-tahun, salah satu tahapan tersebut adalah proses 
sandblasting. Proses sandblasting dilakukan untuk meningkatkan hasil pengecatan pada kapal. Menurut Sulistyo dan Setyarini (2011) proses sandblasting adalah proses pembersihan atau persiapan permukaan logam dengan menembakkan material abrasive berupa pasir silika secara paksa ke permukaan material. Penyemprotan pasir ini digunakan dalam berbagai aplikasi seperti untuk menghilangkan karat, debu, kotoran dan membentuk kekasaran permukaan material supaya rata sehingga ketika proses pengecatan atau pelapisan cat lebih melekat dan produk tersebut akan lebih tahan terhadap korosi.

Berdasarkan Lampiran 2 Peraturan Pemerintah No. 101 Tahun 2014, limbah hasil dari proses sandblasting ditetapkan sebagai limbah B3. Limbah sandblasting berdasarkan sumbernya termasuk sumber spesifik umum dengan kategori bahaya 2 yang memiliki efek tunda (delayed effect). Limbah Sandblasting juga berdampak tidak langsung terhadap manusia dan lingkungan hidup. Limbah sandblasting dikategorikan sebagai limbah B3 karena pada limbah tersebut terindikasi mengandung sejumlah logam berat yang dapat menimbulkan dampak negatif terhadap kesehatan dan lingkungan. Paparan debu limbah sandblasting secara terus menerus berpotensi menyebabkan iritasi pada kulit, gangguan pernapasan bahkan silikosis. Pembuangan limbah sandblasting ke lingkungan tanpa pengolahan yang baik dapat mencemari udara (Sukandar \& Wildaniand, 2010).

Udara merupakan salah satu elemen penting dalam kehidupan makhluk hidup, sehingga apabila terjadi pencemaran udara maka akan berdampak langsung terhadap kesehatan manusia dan menganggu kesetimbangan alam. Peraturan Pemerintah Republik Indonesia No. 41 Tahun 1999 Tentang Pengendalian Pencemaran Udara menjelaskan bahwa Setiap kegiatan wajib melakukan upaya penanggulangan atau pemulihan apabila kegiatan tersebut menyebabkan pencemaran udara. Sedangkan, pada proses sandblasting di industri kapal memiliki potensi untuk mencemari lingkungan. Hal ini didukung dengan belum adanya alat pengendalian pencemaran udara atau dust collector di area proses sandblasting. Hasil pengukuran konsentrasi limbah sandblasting di lapangan menunjukkan rata- rata konsentrasi partikulat limbah sandblasting sebesar $6654,54 \mathrm{mg} / \mathrm{m}^{3}$. Baku mutu konsentrasi partikulat sesuai PERGUB JATIM Nomor 10 Tahun 2009 sebesar 350 $\mathrm{mg} / \mathrm{m}^{3}$. Berdasarkan data tersebut disimpulkan bahwa konsentrasi limbah tersebut melebihi baku mutu.

Berdasarkan permasalahan pencemaran udara yang disebabkan oleh proses sandblasting di industri konstruksi kapal, maka perlu dilakukan karakterisasi limbah sandblasting. Karakteristik digunakan untuk memilih teknologi yang sesuai, serta mengaplikasikan teknologi pengendali limbah sandblasting yang tepat. Pemilihan dan aplikasi yang tepat dapat menyelesaikan permasalahan pencemaran oleh limbah sandblasting dari kegiatan konstruksi kapal.

\section{METODE PENELITIAN}

Tahapan kegiatan penelitian ini meliputi: pengambilan sampel, pengukuran konsentrasi, pengukuran diameter, pengukuran kandungan logam berat dan penentuan jenis alat pengendali untuk limbah sandblasting.

\section{Pengambilan sampel dan pengukuran nilai konsentrasi limbah sandblasting}

Penelitian karakterisasi dan pemilihan alat pengendali limbah sandblasting di bengkel blasting industri konstruksi kapal dimulai dengan mempersiapkan alat dan bahan untuk pengambilan sampel partikulat di bengkel blasting. Peralatan yang digunakan dalam pengambilan sampel ini adalah HVAS. Metode ini cocok digunakan untuk pengambilan sampel partikulat berupa Total Suspended Partikulat (TSP). Kecepatan pompa untuk menghisap sebesar 1.000-1.500 liter/menit dan memiliki porositas sebesar 0,30-0,45 $\mu \mathrm{m}$. Bentuk alat HVAS ditunjukkan pada Gambar 1.

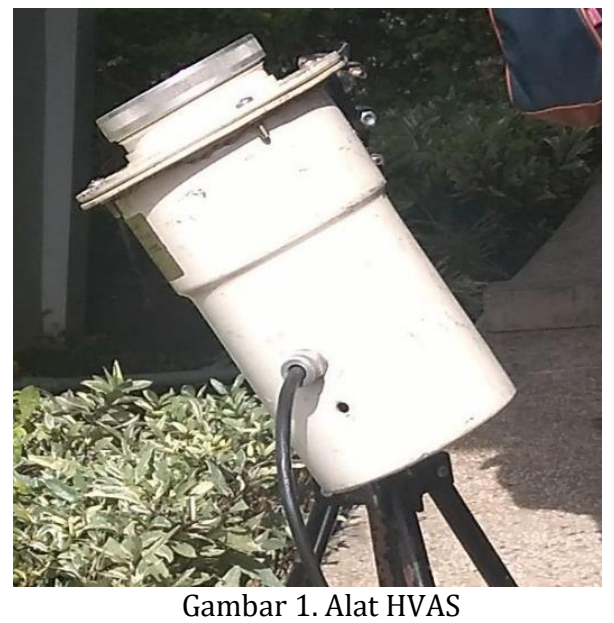


Pengambilan sampel limbah sandblasting dilakukan di salah satu bengkel blasting industri konstruksi kapal yang merupakan sumber limbah blasting tersebut dihasilkan. Pengambilan sampel limbah sandblasting sebanyak 8 titik pengambilan di sekitar sumber kegiatan blasting, hal ini dilakukan untuk mendapatkan sampel yang bisa mewakili dengan kondisi di lapangan. Detail 8 titik lokasi pengambilan sampel di tunjukkan Gambar 2.

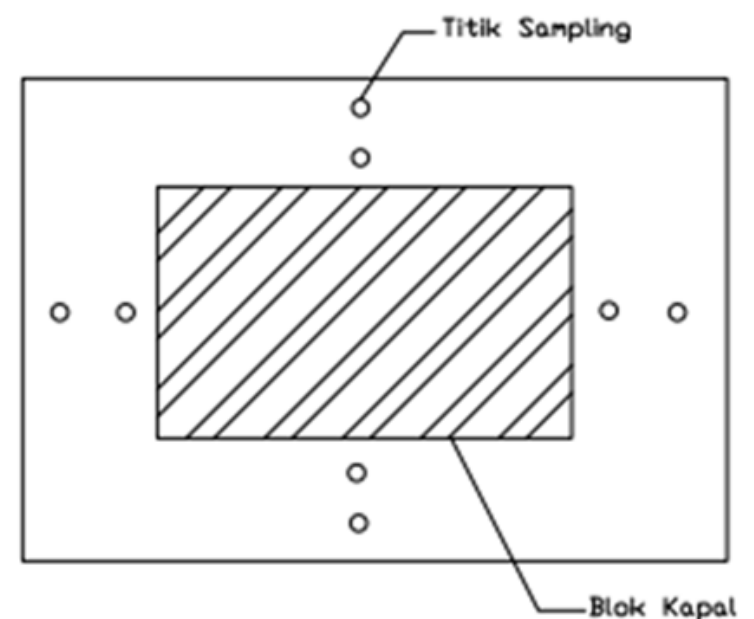

Gambar 2. Titik Pengambilan Sampel Limbah Sandblasting di Bengkel Blasting

Metode pengambilan sampel limbah sandblasting yang digunakan yaitu metode sampling udara sesaat atau grap sampling. Hasil dari pengambilan sampel selanjutnya dianalisa konsentrasinya dengan metode gravimetri, sebelum dan sesudah dilakukan pengambilan sampel harus diketahui berat kertas saringnya. Nilai konsentrasi partikulat bisa didapatkan dengan metode gravimetri sesuai dengan Standar Nasional Indonesia (SNI) 19-17119.3-2005 tentang cara uji TSP menggunakan peralatan HVAS. Rumus yang digunakan sebagai berikut:

$$
\mathrm{C}=\frac{\left(W_{2}-W_{1}\right) \times 10^{6}}{V}
$$

Dimana:

$\mathrm{C} \quad=$ Konsentrasi partikel $\left(\mathrm{mg} / \mathrm{Nm}^{3}\right)$

$\mathrm{W}_{2} \quad=$ Berat filter akhir (g)

$\mathrm{W}_{1} \quad=$ Berat filter awal (g)

$\mathrm{V} \quad=$ Volume contoh uji udara $\left(\mathrm{m}^{3}\right)$

Masing-masing titik sampling didapatkan nilai konsentrasinya, sehingga didapatkan 8 nilai konsentrasi limbah sandblasting. Konsentrasi limbah sandblasting diperlukan dalam mendesain alat pengendali, khususnya untuk kebutuhan prosentase removal.

\section{Alat dan Bahan Penelitian}

Pengambilan sampel untuk menentukan nilai konsentrasi limbah sandblasting dibutuhkan beberapa alat sebagai berikut:

- Desikator

- Timbangan analitik

- Penjepit

- High volume air sampler

- Scanning electron miscroscopy

- Atomic absorbtion spekgrophotometri

- Global positioning system

Sedangkan untuk bahan yang perlukan dalam pengambilan sampel partikulat untuk menentukan nilai konsentrasinya adalah kertas saring

\section{Pengukuran Diameter dan Kandungan Logam Berat Limbah Sandblasting}

Pengambilan sampel limbah sandblasting yang sudah dilakukan ditahap sebelumnya juga berfungsi untuk mendapatkan diameter dan kandungan logam berat pada limbah sandblasting tersebut. Diameter limbah sandblasting didapatkan dengan cara memindai partikulat dengan menggunakan sinar elektron berenergi tinggi dan pembesaran objek pada alat yang disebut dengan SEM. Hasil dari alat SEM nantinya berupa gambar morfologi dan nilai ukuran dari partikulat.

Pengujian selanjutnya adalah untuk menentukan kandungan logam berat berupa besi ( $\mathrm{Fe}$ ) dan Aluminium (Al) dengan metode AAS. Metode ini adalah suatu analisis secara spektroskopi serapan atom yang merupakan analisis instrumen yang berdasarkan adanya interaksi berupa absorpsi radiasi elektromagnetik dari sumber radiasi oleh atom yang dianalisis dalam suatu sampel. Pengukuran kandungan logam berat menggunakan AAS karena merupakan metode yang popular untuk analisa logam.

Pengujian $\mathrm{Fe}$ dan $\mathrm{Al}$ ini bertujuan untuk mengidentifikasi nilai ambang batas faktor fisika dan kimia di tempat kerja sesuai peraturan Menteri tenaga kerja dan transmigrasi no. 13 tahun 2011. Langkah terakhir dalam penelitian ini yaitu menentukan jenis alat pengolahan limbah sandblasting yang tepat berdasarkan karakteristik limbah sandblasting. 


\section{Penentuan Jenis dan Prosentase Penyisihan Alat Pengendali}

Penentuan jenis alat pengendali limbah sandblasting harus tepat sesuai dengan kebutuhan, misalnya dari segi efisiensi, biaya dan luas lahan. Klasifikasi alat pengendali partikulat berdasarkan jenis pengolahannya bisa dibedakan menjadi pretreatment dan advance sesuai pada Tabel 1 .

Tabel 1. Jenis Alat Pengolahan Partikulat

\begin{tabular}{clc} 
No & Nama Alat & Jenis Pengolahan \\
\hline 1 & GSC & Pretreatment \\
2 & Cyclone & Pretreatment \\
3 & Scrubber & Advance \\
4 & Bag Filter & Advance \\
5 & ESP & Advance \\
\hline \multicolumn{2}{l}{ Sumber: Schnelle, Dunn dan Terner, 2017 }
\end{tabular}

Langkah awal dalam penetuan jenis alat pengendali limbah sandblasting pada penelitian ini berdasarkan ukuran dari limbah sandblasting terlebih dahulu. Faktor-faktor lain juga akan dipertimbangkan dalam pemilihan alat pengendali. Pemilihan alat pengendali dan prosentase (\%) removal mengacu ke Schifftner (2013).

\section{HASIL DAN PEMBAHASAN}

Langkah awal dari tahapan karakterisasi limbah sandblasting adalah menentukan konsentrasi dari limbah tersebut. Hasil dari pengukuran konsentrasi limbah sandblasting di masing-masing titik sampling di tunjukkan pada Tabel 1.

Tabel 1. Konsentrai Partikulat Limbah Sandblasting

\begin{tabular}{ccc}
\hline No & Sampel & Konsentrasi $\left(\mathbf{m g} / \mathbf{m}^{3}\right)$ \\
\hline 1 & $\mathrm{~A}$ & 587,87 \\
\hline 2 & $\mathrm{~B}$ & 4490,91 \\
\hline 3 & $\mathrm{C}$ & 20842,42 \\
\hline 4 & $\mathrm{D}$ & 260,61 \\
\hline 5 & $\mathrm{E}$ & 15181,82 \\
\hline 6 & $\mathrm{~F}$ & 303,03 \\
\hline 7 & $\mathrm{G}$ & 781,82 \\
\hline 8 & $\mathrm{H}$ & 10787,88 \\
\hline & Rata - rata & 6654,54
\end{tabular}

Berdasarkan hasil pengujian konsentrasi limbah sandblasting dengan metode gravimetri pada 8 titik, didapatkan nilai konsentrasi yang berbeda-beda. Pengambilan titik yang didekat sumber pencemar akan menghasilkan konsentrasi yang lebih besar dibandingkan dengan titik yang lebih jauh dari p-ISSN: 2460-8815, e-ISSN: 2549-1652 sumber pencemar. Hasil pengukuran tersebut didapatkan nilai rata-rata konsentrasi partikulat limbah sandblasting sebesar $6654,54 \mathrm{mg} / \mathrm{m}^{3}$ apabila dibandingkan dengan baku mutu partikulat sebesar $350 \mathrm{mg} / \mathrm{m}^{3}$ yang diatur pada Peraturan Gubernur Nomor 10 Tahun 2009, dapat disimpulkan bahwa konsentrasi limbah tersebut melebihi baku mutu.

Sampel limbah sandblasting yang sudah diambil kemudian dipindai dengan menggunakan sinar elektron berenergi tinggi dan pembesaran objek sebesar 2000 kali supaya limbah sandblasting lebih jelas terlihat dan mendapatkan nilai diameter yang akurat. Detail ukuran limbah sandblasting ditunjukkan pada Gambar 3-6.

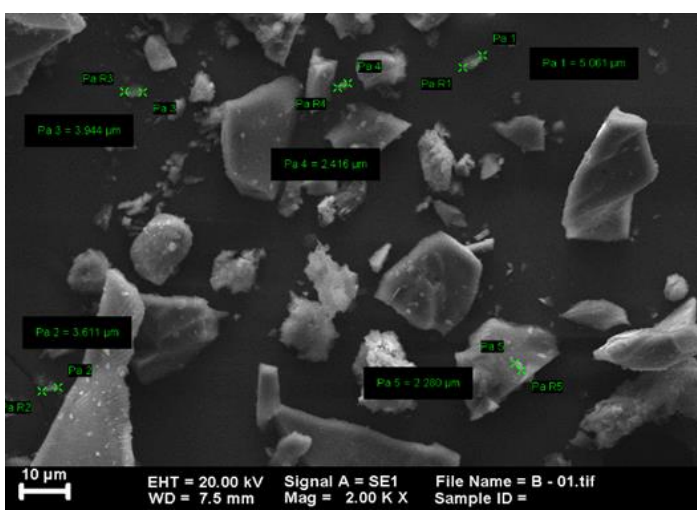

Gambar 3. Hasil Pengujian SEM Sampel 1

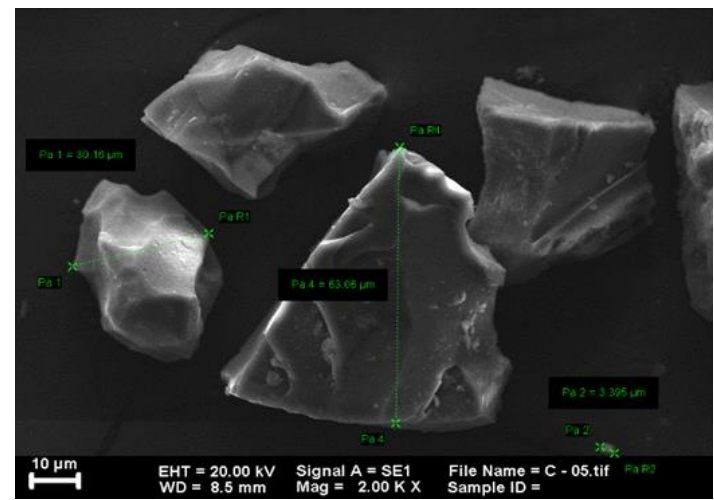

Gambar 4. Hasil Pengujian SEM Sampel 2

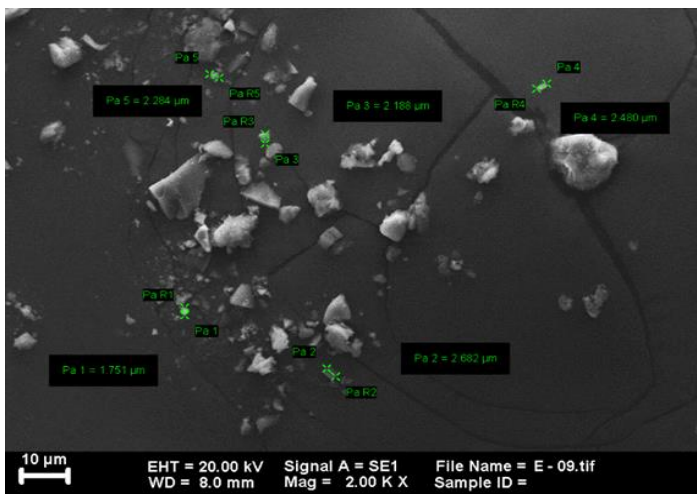

Gambar 5. Hasil Pengujian SEM Sampel 3 


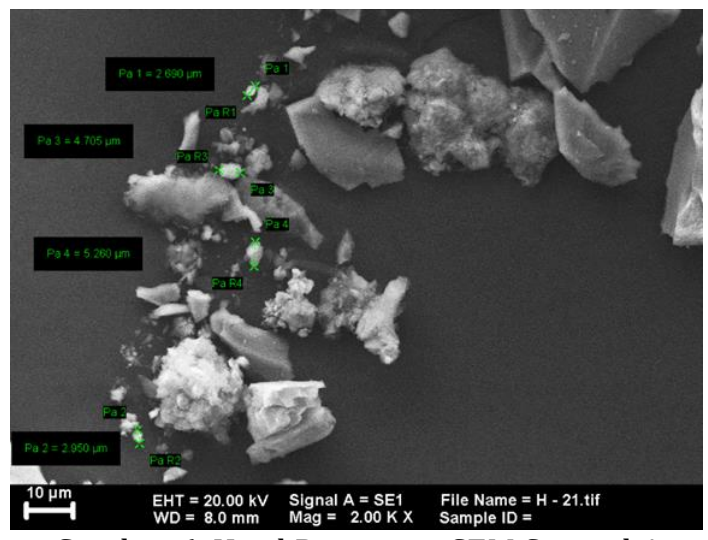

Gambar 6. Hasil Pengujian SEM Sampel 4

Bentuk dan ukuran limbah sandblasting berbeda-beda meskipun diambil pada lokasi yang sama Hasil pembacaan ukuran partikulat limbah sandblasting dari bengkel blasting konstruksi kapal sampel 1-4, didapatkan beberapa ukuran partikulat sesuai dengan Tabel 2.

Tabel 2. Ukuran Partikulat Limbah Sandblasting

\begin{tabular}{|c|c|c|}
\hline No & $\begin{array}{c}\text { Kode } \\
\text { sampel }\end{array}$ & Ukuran partikulat $(\mu \mathrm{m})$ \\
\hline \multirow{5}{*}{1} & \multirow{5}{*}{1} & 2,28 \\
\hline & & 2,42 \\
\hline & & 3,61 \\
\hline & & 3,94 \\
\hline & & 5,06 \\
\hline \multirow{3}{*}{2} & \multirow{3}{*}{2} & 3,39 \\
\hline & & 30,16 \\
\hline & & 63,06 \\
\hline \multirow{5}{*}{3} & \multirow{5}{*}{3} & 1,751 \\
\hline & & 2,188 \\
\hline & & 2,284 \\
\hline & & 2,480 \\
\hline & & 2,682 \\
\hline \multirow{4}{*}{4} & \multirow{4}{*}{4} & 2,950 \\
\hline & & 2,600 \\
\hline & & 4,705 \\
\hline & & 5,260 \\
\hline
\end{tabular}

Berdasarkan hasil pembacaan SEM mulai sampel 1-4 didapatkan ukuran limbah sandblasting yang berbeda-beda mulai dari yang terkecil 1,75 $\mu \mathrm{m}$ sampai dengan ukuran yang paling besar $63,06 \mu \mathrm{m}$, ukuran limbah sandblasting ini akan digunakan sebagai dasar dalam pemilihan teknonologi pengendali yang sesuai. Pengukuran diameter limbah sandblasting jika sudah dilakukan selanjutnya dilakukan pengujian kandungan logam berat pada limbah sandblasting tersebut, hasil uji kandungan $\mathrm{Fe}$ dan $\mathrm{Al}$ yang terdapat dalam limbah sandblasting menggunakan AAS dapat dilihat pada Tabel 3 .
Tabel 3. Hasil Pengukuran Kandungan Logam Berat Pada Limbah Sandblasting

\begin{tabular}{llcc}
\hline No & $\begin{array}{l}\text { Kode } \\
\text { Sampel }\end{array}$ & $\begin{array}{c}\text { Parameter Fe } \\
\left(\mathrm{mg} / \mathrm{m}^{3}\right)\end{array}$ & $\begin{array}{c}\text { Parameter Al } \\
\left(\mathrm{mg} / \mathrm{m}^{3}\right)\end{array}$ \\
\hline 1 & 01 & 1,66 & 2,78 \\
\hline 2 & 02 & 0,50 & 0,41 \\
\hline 3 & 03 & 1,17 & 1,93 \\
\hline 4 & 04 & 3,22 & 4,05 \\
\hline \multicolumn{2}{l}{ Rata - rata } & 1,64 & 2,29 \\
\hline
\end{tabular}

Hasil pengukuran kandungan logam berat pada limbah sandblasting terdapat 2 jenis logam berat yang dominan yaitu $\mathrm{Fe}$ dan $\mathrm{Al}$. Nilai rata-rata konsentrasi masing-masing $1,64 \mathrm{mg} / \mathrm{m}^{3}$ dan $2,29 \mathrm{mg} / \mathrm{m}^{3}$. Berdasarkan peraturan Menteri tenaga kerja dan transmigrasi nomor 13 tahun 2011 tentang nilai ambang batas faktor fisika dan kimia di tempat kerja menjelaskan bahwa nilai ambang batas untuk logam berat sebesar $10 \mathrm{mg} / \mathrm{m}^{3}$. Hasil pengukuran logam berat apabila dibandingkan dengan ambang batas tersebut tidak ada sampel yang melebihi ambang batas.

Karakteristik dari limbah sandblasting sudah diketahui pada tahap sebelumnya, maka selanjutnya yaitu menentukan jenis teknologi pengendali limbah sandblasting. Pemilihan jenis teknologi pengendalian limbah sandblasting berdasarkan ukuran partikulat yang sudah didapatkan dengan pengukuran SEM sebelumnya. Ukuran limbah sandblasting dari hasil kegiatan proses blasting di industry kapal ini bisa dikelompokkan menjadi dua, yaitu kecil dan besar. Kecil berukuran antara 1,751-5,260 $\mu \mathrm{m}$ dan kelompok ukuran besar anatar 30,16-63,06 $\mu \mathrm{m}$. Pembagian kelompok ini berdasarkan selisih ukuran yang besar, sehingga membutuhkan teknologi pengolahan yang berbeda. Ukuran partikulat tersebut diplotkan pada Gambar 7 untuk mendapatkan jenis teknologi pengendalian yang sesuai berdasarkan ukuran partikulat.

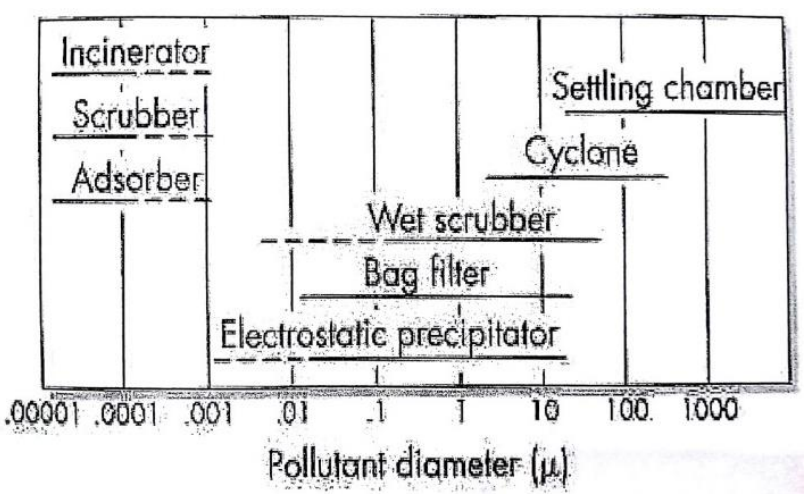

Gambar 7. Teknologi Dust collector Berdasarkan Ukuran Partikulat (Schifftner, 2013) 
Mengacu ke selisih ukuran partikulat yang didapatkan dan mengacu ke Gambar 7 maka direkomendasikan untuk membuat pengoalahan pendahuluan dan pengolahan lanjutan. Berdasarkan kelompok ukuran partikulat dan sesuai Gambar 7 tentang pemilihan teknologi dust collector, maka dapat diambil suatu tindakan untuk memilih teknologi cyclone atau gravity settling chamber sebagai teknologi pengendalian awal. Pemilihan alat tersebut untuk penyisihan limbah sandblasting ukuran kelompok besar yaitu ukuran 30,16-63,06 $\mu \mathrm{m}$. Teknologi pengolahan lanjutan bisa memilih teknologi wet scrubber atau bag filter atau electrostatic precipitator. Teknologi tersebut untuk penyisihan limbah sandblasting ukuran kelompok kecil yaitu ukuran 1,75-5,26 $\mu$ m.

Teknologi pengendalian yang telah dipilih bisa diketahui prosentase (\%) penyisihannya, sehingga designer bisa memilih alat pengendali yang sesuai kebutuhan berapa prosentase penyisihan yang dinginkan. Penentuan prosentase (\%) penyisihan berdasarkan Gambar 8, dimana: (A) gravity settling chamber, (B) simple cyclone, (C) highefficiency cyclone, (D) elektrostatic precipitator, $(E)$ spray tower wet scrubber, (F) venturi scrubber dan (G) bag filter.

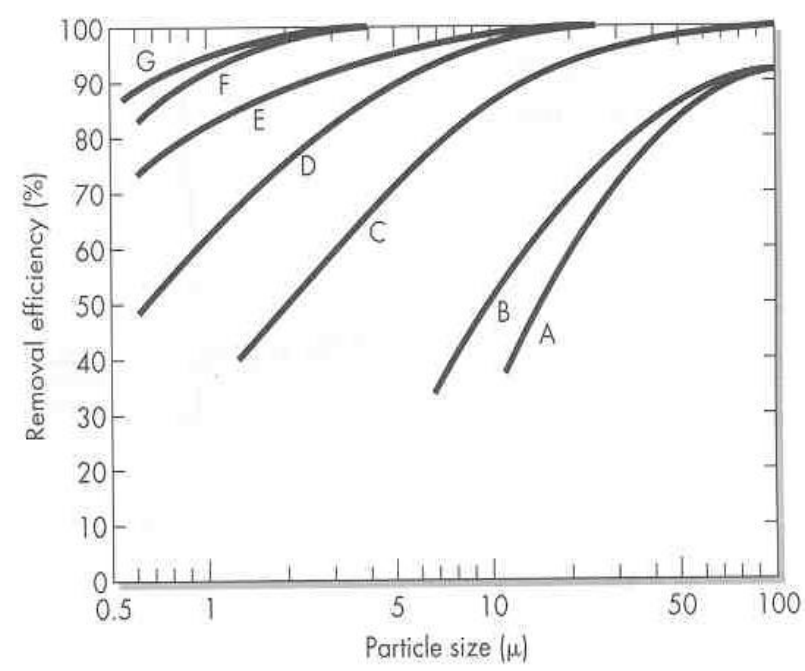

Gambar 8. Prosentase Penyisihan Berdasarkan Ukuran Partikulat

(Schifftner, 2013)

Ukuran limbah sandblasting kelompok besar jika teknologi pengendali pengendalian yang dipilih sebagai penyisihan awal adalah gravity settling chamber berdasarkan Gambar 8 maka didapatkan prosentase (\%) penyisihan untuk limbah sandblasting yang berukuran
30,16-63,06 $\mu \mathrm{m}$ sebesar $\pm 77,5 \%$. Teknologi pengendalian penyisihan awal jika menggunakan simple cyclone maka prosentase (\%) penyisihan yang didapatkan sebesar \pm $84 \%$.

Teknologi penyisihan lanjutan limbah sandblasting dengan kelompok ukuran kecil yaitu ukuran 1,75-5,26 $\mu \mathrm{m}$ jika menggunakan teknologi wet scrubber prosentase (\%) penyisihan yang didapatkan $\pm 90 \%$. Teknologi lanjutan lainnya jika memilih bag filter maka prosentase (\%) penyisihan sebesar $\pm 97 \%$ dan jika teknologi yang dipilih adalah Electrostatic Precipitator maka prosentase (\%) penyisihan sebesar $\pm 85 \%$. Pemilihan teknologi pengendali berdasarkan ukuran partikulatnya sifatnya tidak mutlak, faktor-faktor lain dalam memilih teknologi pengendali bisa dipertimbangkan misalnya kriteria lain seperti biaya, luas lahan, dan pertimbanganpertimbangan lain yang diperlukan seperti contoh pada tabel 4 .

Tabel 4. Kriteria Pemilihan Teknologi Pengendali Partikulat

\begin{tabular}{|c|c|c|c|c|}
\hline \multirow[b]{2}{*}{$\begin{array}{l}\text { Dust } \\
\text { collector }\end{array}$} & \multicolumn{4}{|c|}{ Aspek } \\
\hline & Biaya $^{*}$ & Lahan & $\begin{array}{l}\text { Tenaga } \\
\text { Kerja***** }\end{array}$ & Problem ${ }^{* * * * * * *}$ \\
\hline ESP & $\begin{array}{l}\text { Tinggi } \\
\text { sekitar } \\
\$ 1,840,00\end{array}$ & Luas ** & $\begin{array}{l}\text { Cukup } \\
\text { Ahli }\end{array}$ & $\begin{array}{l}\text { Perlu } \\
\text { memperhatika } \\
\text { n resistansi } \\
\text { partikulat }\end{array}$ \\
\hline Bag filter & $\begin{array}{l}\text { Menengah } \\
\text { sekitar } \\
\$ 569,000\end{array}$ & Luas ** & Ahli & $\begin{array}{l}\text { Tidak bisa } \\
\text { dilakukan } \\
\text { untuk } \\
\text { temperatur } \\
\text { yang tinggi }\end{array}$ \\
\hline $\begin{array}{l}\text { Wet } \\
\text { Scrubber }\end{array}$ & $\begin{array}{l}\text { Rendah } \\
\text { sekitar } \\
\$ 159.000 \\
\end{array}$ & $\begin{array}{l}\text { Cukup } \\
\text { luas } \\
* * * * *\end{array}$ & Ahli & $\begin{array}{l}\text { Menimbulkan } \\
\text { Permasalahan } \\
\text { air }\end{array}$ \\
\hline
\end{tabular}

*Environmental Protection Agency, 1999.

**Firmansyah, 2015 \& Theodore, L. 2008

****Raharja, 2013.

***** Schifftner, 2013

******David and Alley, 2010.

\section{KESIMPULAN}

Kesimpulan yang bisa didapatkan dari penelitian ini antara lain:

- Konsentrasi rata-rata limbah sandblasting dari proses blasting di indsutri konstruksi kapal sebesar $6654,54 \mathrm{mg} / \mathrm{m}^{3}$

- Kandungan logam berat berupa Fe dan Al masing-masing sebesar 1,64 dan $2,29 \mathrm{mg} / \mathrm{m}^{3}$

- Ukuran limbah sandblasting bisa dibedakan menjadi 2 kategori, yaitu ukuran kelompok besar yaitu ukuran 
30,16-63,06 $\mu \mathrm{m}$ dan ukuran kelompok kecil yaitu ukuran 1,75-5,26 $\mu \mathrm{m}$

- Prosentase (\%) removal yang didapatkan jika memilih gravity settling chamber sebesar $\pm 77,50 \%$, jika memilih simple cyclone maka prosentase (\%) penyisihan yang didapatkan sebesar $\pm 84 \%$ untuk penyisihan awal. Penyisihal lanjutan jika memilih wet scrubber prosentase (\%) penyisihan yang didapatkan \pm 90\%, jika memilih teknologi Bag Filter maka prosentase (\%) penyisihan sebesar $\pm 97 \%$ dan jika teknologi yang dipilih adalah Electrostatic Precipitator maka prosentase (\%) penyisihan sebesar $\pm 85 \%$.

\section{DAFTAR PUSTAKA}

Cooper, David. \& Alley, F. (2010). Air Pollution Control: A Design Approach, Fourth Edition. Waveland Press.

Firmansyah, Agung. Dkk (2015). Perencanaan dan Pembuatan Model Miniatur Elektrostatic Precipitator untuk mengurangi Partikel Debu Gas Buang Pabrik Gula Krebet Baru I Kabupaten Malang. Jurnal Electro, Vol 2, No. 2, 75-81.

Peraturan Menteri Tenaga Kerja dan Transmigrasi Nomor 13 Tahun 2013 Tentang Ambang Batas Faktor Fisika dan Kimia di Tempat Kerja

Peraturan Pemerintah Republik Indonesia Nomor 101 Tahun 2014 Tentang Pengelolaan Limbah Bahan Berbahaya dan Beracun.

Peraturan Pemerintah Republik Indonesia Nomor 41 Tahun 1999 Tentang Pengendalian Pencemaran Udara.

Peraturan Gubernur Jawa Timur Republik Indonesia Nomor 10 Tahun 2009 Tentang Baku Mutu Sumber Emisi Tidak Bergerak

Raharja, Setya, A. (2013). Perancangan Dust Collector Di PT. Keramik Diamond Industries. Surabaya.

Schnelle, Karl B., Dunn, Russel F. \& Ternes, Mary Ellen. 2017. Air Pollution Control Technology Handbook. CRC Press

Schifftner, Kenneth. (2013). Air Pollution Control Equipment Selection Guide, Second Edition. CRC Press

SNI 19-7119.3. (2005). Udara ambien Bagian 3: Cara Uji Partikel Tersuspensi Total Menggunakan Peralatan High
Volume Air Sampler (HVAS) dengan Metode gravimetri.

Sukandar, \& Wildaniand, N. (2010). Studi Awal Pemanfaatan Limbah Sandblasting Sebagai Koagulan. Jurnal Teknik Lingkungan, Vol.16, No.1, 93102.

Sulistyo, E., \& Setyarini, P. H. (2010). Studi Awal Pemanfaatan Limbah Sandblasting Sebagai Koagulan. Jurnal Teknik Lingkungan Volume 16 Nomor 1, 93-102.

Theodore, Louis. (2008). Air Pollution Control Equipment Calculations. New Jersey: John Wiley \& Sons, Inc., Publication.

U.S. EPA (United States Environmental Protection Agency). (1999). Electrostatic Precipitator. Washington, DC. 